\title{
Relationship between testicular lesion and hormone levels in male rats infected with Trypanosoma evansi
}

\author{
LUCIANA FACCIO ${ }^{1}$, ALEKSANDRO S. DA SILVA ${ }^{2}$, ALEXANDRE A. TONIN ${ }^{3}$, \\ LUCAS OBERHERR ${ }^{4}$, LUCAS T. GRESSLER ${ }^{1}$, CAMILA B. OLIVEIRA $^{1}$, DIONATAN T. OLIVEIRA $^{1}$, \\ MANUELA B. SANGOI ${ }^{5}$, RAFAEL N. MORESCO ${ }^{5}$, YASMIN N. SAMARA ${ }^{6}$, MARCELO VEIGA ${ }^{6}$, \\ MARTA M.M.F. DUARTE ${ }^{7}$ and SILVIA G. MONTEIRO ${ }^{1}$ \\ ${ }^{1}$ Departamento de Microbiologia e Parasitologia, Universidade Federal de Santa Maria, \\ Avenida Roraima, Prédio 20, Camobi, 97105-900 Santa Maria, RS, Brasil \\ ${ }^{2}$ Departamento de Zootecnia, Universidade do Estado de Santa Catarina, \\ Rua Beloni Trombeta Zanin, Prédio 680E,Santo Antonio, 89815-630 Chapecó, SC, Brasil \\ ${ }^{3}$ Departamento de Clínica de Pequenos Animais, Universidade Federal de Santa Maria, Hospital Veterinário, \\ Avenida Roraima, Prédio 97, Camobi, 97105-900 Santa Maria, RS, Brasil \\ ${ }^{4}$ Avenida Roraima, Prédio 22, Camobi 97105-900, Santa Maria, RS, Brasil \\ ${ }^{5}$ Departamento de Análises Clínicas e Toxicológicas, Universidade Federal de Santa Maria, \\ Avenida Roraima, Prédio 26, Camobi, 97105-900 Santa Maria, RS, Brasil \\ ${ }^{6}$ Departamento de Morfologia, Universidade Federal de Santa Maria, \\ Avenida Roraima, Prédio 19, Camobi, 97105-900 Santa Maria, RS, Brasil \\ ${ }^{7}$ Universidade Luterana do Brasil, Campus Santa Maria, BR 287, Km 252, \\ Trevo Maneco Pedroso, Caixa Postal 21834, 97020-001 Santa Maria, RS, Brasil
}

Manuscript received on April 29, 2013; accepted for publication on January 3, 2014

\begin{abstract}
The aim of this study was to evaluate the relationship between testicular lesions and hormone levels in rats experimentally infected with Trypanosoma evansi. For that, the measurement of reproductive hormones, histopathology and biomarkers of cellular injury were carried out in twenty-four animals, which were divided into two groups with 12 animals each. Group A was the negative control, or uninfected, while group B was composed by animals infected with $T$. evansi. Both groups were divided again into two other subgroups $(\mathrm{n}=6)$, from which serum and testicular fragments were collected on days 5 (A1 and B1) and 15 (A2 and $\mathrm{B} 2$ ) post-infection (PI). The morphological analysis showed increased alterations of head and tail of sperm in infected rats when compared with those of the control group. A significant reduction $(\mathrm{P}<0.01)$ in the levels of LH, FSH, testosterone and estradiol, associated with an increase in cortisol, was observed in serum of group B when compared with negative control. Additionally, NOx, lipid peroxidation and protein oxidation were enhanced in testicles, indicating the occurrence of cellular lesion. On histopathology, it was possible to observe testicular degeneration, among other disorders in infected animals. Therefore, based on these results, it is possible to conclude that the experimental infection with T. evansi caused changes in the levels of the main hormones of male rats associated with cellular injury.
\end{abstract}

Key words: protozoa, Wistar rats, testicular lesion, reproduction, oxidative stress.

Correspondence to: Luciana Faccio

E-mail:1ucianabfaccio@gmail.com 


\section{INTRODUCTION}

Trypanosoma evansi is the etiological agent of the disease known as "mal das cadeiras" or "surra" that affects domestic and wild animals (Silva et al. 2002), with reports of several clinical and pathological manifestations (Jittapalapong et al. 2009, Mbaya et al. 2011). With regards to reproductive disturbances, T. evansi have already been described in both males and females, as well as in different animal species. In males, it causes degeneration of the seminiferous tubules, spermatogenic cells and spermatids in the ducts of the epididymis (Shehu et al. 2006); testicular atrophy, decrease of epididymal sperm reserves, widespread and severe testicular degeneration with necrosis and calcification (Maudlin et al. 2004). In infected females with $T$. evansi the occurrence of abortion, repeated estrus, birth of weak animals, stillbirths, and temporary or permanent anestrus were reported (Silva et al. 2004, Batista et al. 2007, 2008, Bezerra et al. 2006).

With regards to endocrinology, the reciprocal endocrinological interactions between host and parasite are receiving increased attention (Escobedo et al.2005), since hormones regulate a variety of cellular and physiological functions of organisms, such as growth, differentiation and specially reproduction (Derijk and Berkenbosch 1991, Grossman et al. 1991). In reproductive endocrinology, hormonal evaluation is needed, especially in the clinical evaluations of infertility cases in males and females. In this sense, there is, for instance, another protozoan that belongs to the family Trypanosomatidae, Trypanosoma vivax, which has been reported as a causative agent of reproductive problems in domestic mammals (Mbaya et al. 2011). Studies showed that trypanosomosis by $T$. vivax causes a series of directly or indirectly related reproductive disorders on cattle herd due to the degeneration of the hypothalamus, pituitary and gonads, with consequent alterations in plasma concentrations and in the secretion of hormones needed for reproduction in both sexes (Sekoni 1994). In males, it is well known that $T$. vivax is responsible for testicular and epididymal lesions, decreased semen quality due to decreased sperm concentration, decrease of volume, changes in sperm morphology and reduced number of spermatogenic cells (Sekoni et al. 1990, Sekoni 1994). There are also reported cases of infertility and sterility in animals chronically affected with $T$. vivax (Sekoni et al. 2004).

Histopathological analysis cannot often show mild tissue damage, and for this reason, the relationship between tissue damage and oxidative stress is widely studied. There are different methods for the evaluation of cell lesion/ oxidative stress, mainly through the employment of biomarkers. In this sense, the lipid peroxidation is a general mechanism by which free radicals can induce tissue damage and is implicated in several pathological conditions (Halliwell and Chirico 1993). The assessment of Thiobarbituric acid reactive substances (TBARS) probably is the most commonly applied method for the measurement of lipid peroxidation (Esterbauer 1993). Along with TBARS, another protein biomarker for oxidative stress, described by Witko-Sarsat et al. (1998), is the advanced oxidation protein products (AOPP). Cytological dysfunction is believed to be correlated with oxidative stress via modification of biological structures and formation of AOPP. These protein products might be regarded as a family of compounds containing abundant dityrosines, which allow cross linking, disulfide bridges, and carbonyl groups (Capeillére-Blandin et al. 2004). This may indicate that AOPP acts as markers of oxidative stress, and may contribute to cytological dysfunction (Descamps-Latscha et al. 2005). Our last biomarker employed in this study was the nitric oxide (NO), mainly due its generation and high concentrations observed in camels and horses infected by $T$. evansi (Saleh et al. 2009, Ranjithkumar et al. 2011). $\mathrm{NO}$ is an uncharged free radical that is produced during the enzymatic conversion of L-arginine to L-citrulline by members of the nitric oxide synthase 
(NOS) family of proteins: endothelial NOS and neuronal NOS (functioning in a calcium-dependent fashion); and inducible NOS (functioning in a calcium independent fashion) (Stuehr 1999). The measurement of NO levels may be a parameter to oxidative stress status, and suitable for diagnosis and treatment of diseases (Lopes et al. 1997, Chatkin 2000, Santiago et al. 2000). Oxidative stress has been related increasingly to the onset and/ or progression of a growing number of diseases, and therefore, its evaluation through biomarkers is extremely important and it represents a useful laboratorial tool (Da Silva et al. 2012).

This study was planned and elaborated based on the reproductive problems which cause economic losses, as well as on the lack of research about the mechanisms of action of T. evansi in the hormonal and reproductive system of males, specially related to histological changes of testicular tissue. Therefore, the aim of this study was to evaluate the relationship between testicular lesions and hormone levels in rats experimentally infected with Trypanosoma evansi.

\section{MATERIALS AND METHODS}

ANIMALS AND IsOLATE OF T. evansi

Twenty-four Wistar rats (Rattus norvegicus), males, divided into two groups (A and B) with 12 animals each were used in this study. They were kept in cages, at room temperature and humidity controlled $\left(25^{\circ} \mathrm{C}, 70 \% \mathrm{RH}\right)$, fed with commercial ration and receiving water ad libitum. All the animals were submitted to an adaptation period of 10 days, showing perfect health condition and behavior at the onset of the experiment (day 0 ). The isolate of $T$. evansi used was obtained from a naturally infected dog (Colpo et al. 2005), maintained cryopreserved in liquid nitrogen at laboratory environment. Prior to the infection, it was reactivated through biological passage in rats, in order to obtain viable parasite, and large volumes of T. evansi in blood samples for posterior inoculation.
This study was approved by the Ethics and animal welfare committee of Universidade Federal de Santa Maria (UFSM) under the number 016/2012.

\section{GROUPS AND TRYPANOSOMA INFECTION}

Group A( $\mathrm{n}=12)$ was composed by uninfected animals - negative control - and group B ( $n=12)$ represented the positive control - infected -. The infection was performed intraperitoneally with $0.1 \mathrm{~mL}$ blood containing $10^{7}$ trypomastigotes. These groups were again divided into two subgroups, A1 and A2, B1 and B2, with six animals each. This procedure was performed aiming at the evaluation of different times of infection (days 5 and 15 post-infection).

\section{SAMPLE COLLECTION}

The parasitemia was monitored daily through blood smears stained by the Romanovsky method, analyzed under optic microscopy at 1000x of magnification, and it was expressed according to the number of trypanosomes per field $(t / f)$. Samples of blood and sperm were collected on days 5 (subgroups A1 and B1) and 15 (subgroups A2 and B2) post-infection (PI). Each animal was anesthetized with isoflurano, and immediately after the anesthesia induction, by cardiac puncture, $5 \mathrm{~mL}$ of blood was collected in order to obtain serum for hormonal measurements. After this procedure the animals were euthanatized and the testicles removed for the collection of fragments for histology and biochemical tests to evaluate tissue lesion.

The adapted methods of Barth and Oko (1989), Johnson (1997) and Celeghini (2005) were used for obtaining of sperm from our experimental animals. Briefly, the sperm collection was performed through small sections in the tail of the epididymis, using a sharp blade. The material remaining on the surface of the blade was transferred to a Petri dish containing $50 \mu \mathrm{L}$ of saline $(0.9 \% \mathrm{NaCl})$ at $36^{\circ} \mathrm{C}$. Then, an aliquot of $20 \mu \mathrm{L}$ was mixed in $6 \mathrm{~mL}$ of distilled water for immobilization of the sperm. 


\section{SPERM MORPHOLOGY}

The sperm morphology analysis was performed by electron microscopy, at magnification of 400 and 1000x. 200 spermatozoids, on average, were analyzed in each animal sample (Blom 1973, Barth and Oko 1989).

\section{HORMONAL EVALUATION}

Evaluation of estradiol, LH, FSH and testosterone was carried out by the technique of EIA (Enzyme Immunoassay), according to the manufacturer's instructions (Cayman Chemical Company, Ann Arbor, MI, USA) and Tietz (1995). The measurement of cortisol was performed by ELISA (Enzyme-Linked Immunosorbent Assay) method, using commercial kit. The results of LH, FSH and testosterone were obtained through spectrophotometer and expressed in $\mathrm{ng} / \mathrm{mL}^{-1}$, estradiol in $\mathrm{pg} / \mathrm{mL}^{-1}$ and cortisol in $\mu \mathrm{g} / \mathrm{dL}^{-1}$.

\section{BIOMARKERS OF CELL INJURY}

To evaluate cell damage in the experimental testes, levels of $\mathrm{NO}_{\mathrm{x}}$ (nitrite/nitrate), TBARS (lipid peroxidation) and AOPP (advanced oxidation protein product) were measured using parameters considered markers of cell injury. For this, testicles samples were homogenized in Tris- $\mathrm{HCl}$ buffer 10 mmoL, $\mathrm{pH} 7.2$, with $160 \mathrm{mmol}$ sucrose $(1: 10 \mathrm{w} / \mathrm{v})$. The samples were centrifuged (3500g for 10 minutes) with the supernatant collected and frozen at $-20^{\circ} \mathrm{C}$ until analysis. The oxidation of proteins was quantified considering the concentration of AOPP, determined by semi-automated method described by Witko-Sarsat et al. (1998), with results expressed in $\mu \mathrm{L}$. TBARS levels were measured according to Jentzsch et al. (1996), with results obtained by spectrophotometry at $535 \mathrm{~mm}$, expressed in $\mu \mathrm{mol}$ $\mathrm{MDA} / \mathrm{mg}$ of protein. NOx levels were measured using the Griess modified method, through the Cobas Mira automated analyzer, with results expressed in $\mu \mathrm{mol} / \mathrm{L}$, and according to the technique described by Tatsch et al. (2011).

\section{HISTOPATHOLOGY}

Testicular samples were collected for histopathology evaluations. They were fixed in buffered formalin $(10 \%)$ and preserved in alcohol $70 \%$. After fixation, they were dehydrated, cleared and embedded in paraffin. For each sample two histological slides were prepared with transverse sections of $6 \mu \mathrm{m}$, stained with hematoxylin-eosin and Gomori trichrome method. In each slide a random grid of 15 points on 5 fields was applied. In these, thickness of the germinal epithelium was measured, with determination of degree of degeneration and the presence of sperm in the tubular lumen.

\section{Statistical ANALYSIS}

The data were tested for normality and transformed when necessary. Sperm morphology and AOPP data were not normally distributed and were ranktransformed before statistical analysis. Posteriorly, the data were subjected to statistical analysis by Student's test, with $\mathrm{P}<0.05$ considered as statistically significant. All quantitative morphometric data (histology) were submitted to ANOVA, while the qualitative data to chi-square with SPSS18. The results were presented as mean and standard deviation.

\section{RESULTS}

\section{PROGRESSION OF PARASITEMIA}

Parasites were observed in blood smears of all infected animals between days 1 and 3 day post-infection (PI). Subsequently, the number of circulating flagellates increased progressively over the days. On day 5 PI the samplecollection from the animals with higher parasitemia (subgroup B1 - 66 t/f) was performed. The other animals kept their parasitemia at low levels during the experiment, with another peak on day 15 PI (C - 21 t/f).

\section{SPERM MORPHOLOGY}

The sperm morphology results are shown in Table I. A significant increase in alteration of the sperm head (tapered head) was observed in the infected group 
TABLE I

Morphological analysis of sperm in rats experimentally infected with Trypanosoma evansi. Results are shown as percentages (\%), based on the evaluation of 200 sperm/animal.

\begin{tabular}{cccc}
\hline $\begin{array}{c}\text { Sperm morphology } \\
(\mathrm{n}=200)\end{array}$ & Days & \multicolumn{2}{c}{$\begin{array}{c}\text { Groups (Results in percentage } \\
(\%)\end{array}$} \\
\hline $\begin{array}{c}\text { Normal } \\
\text { (without }\end{array}$ & 05 & $97.72^{\mathrm{a}}( \pm 1.18)$ & $71.92^{\mathrm{b}}( \pm 10.01)$ \\
alteration) & 15 & $98.04^{\mathrm{a}}( \pm 0.97)$ & $94.39^{\mathrm{b}}( \pm 1.10)$ \\
\hline \multirow{2}{*}{ Tapered head sperm } & 05 & $0.65^{\mathrm{b}}( \pm 0.78)$ & $11.09^{\mathrm{a}}( \pm 8.72)$ \\
& 15 & $0.60^{\mathrm{b}}( \pm 0.44)$ & $2.05^{\mathrm{a}}( \pm 0.98)$ \\
\hline \multirow{2}{*}{ Tail folded sperm } & 05 & $1.38^{\mathrm{b}}( \pm 0.70)$ & $13.74^{\mathrm{a}}( \pm 2.67)$ \\
& 15 & $1.17^{\mathrm{b}}( \pm 0.41)$ & $2.27^{\mathrm{a}}( \pm 0.52)$ \\
\hline \multirow{2}{*}{ Distal drop } & 05 & $0.25^{\mathrm{b}}( \pm 0.18)$ & $3.25^{\mathrm{a}}( \pm 1.73)$ \\
& 15 & $0.10^{\mathrm{b}}( \pm 0.34)$ & $1.29^{\mathrm{a}}( \pm 0.92)$ \\
\hline
\end{tabular}

Note: Means with equal letters, on the same line, do not differ statistically among themselves to $5 \%$ of significance $(\mathrm{P}>0.05)$.

on days 5 and 15 PI. Additionally, changes in the sperm tail and distal drop were observed in a great number of the infected animals, when compared to the uninfected, on days 5 and 15 PI. Sperm morphology was evidently altered in infected rats on day 5 PI when compared to day 15 PI (when the parasitemia was lower).

HORMONES

The results of hormonal dosage and cortisol are shown in Figures 1 and 2. Subgroups B1 and B2 showed a significant decrease in the levels of $\mathrm{LH}$, $\mathrm{FSH}$, testosterone and estradiol on days 5 and $15 \mathrm{PI}$, when compared to their respective control groups $(\mathrm{P}<0.01)$. Cortisol levels in serum was significantly $(\mathrm{P}<0.01)$ increased in infected animals on days 5 and 15 PI compared with the control group.

\section{BIOMARKERS OF CELL INJURY}

The results of biomarkers of cell injury are shown in Table II. Serum levels of $\mathrm{NO}_{\mathrm{x}}$ and TBARS increased significantly $(\mathrm{P}<0.05)$ on days 5 and 15 PI in infected groups, while levels of AOPP increased significantly only on day 5 PI, when they were compared with the control group.
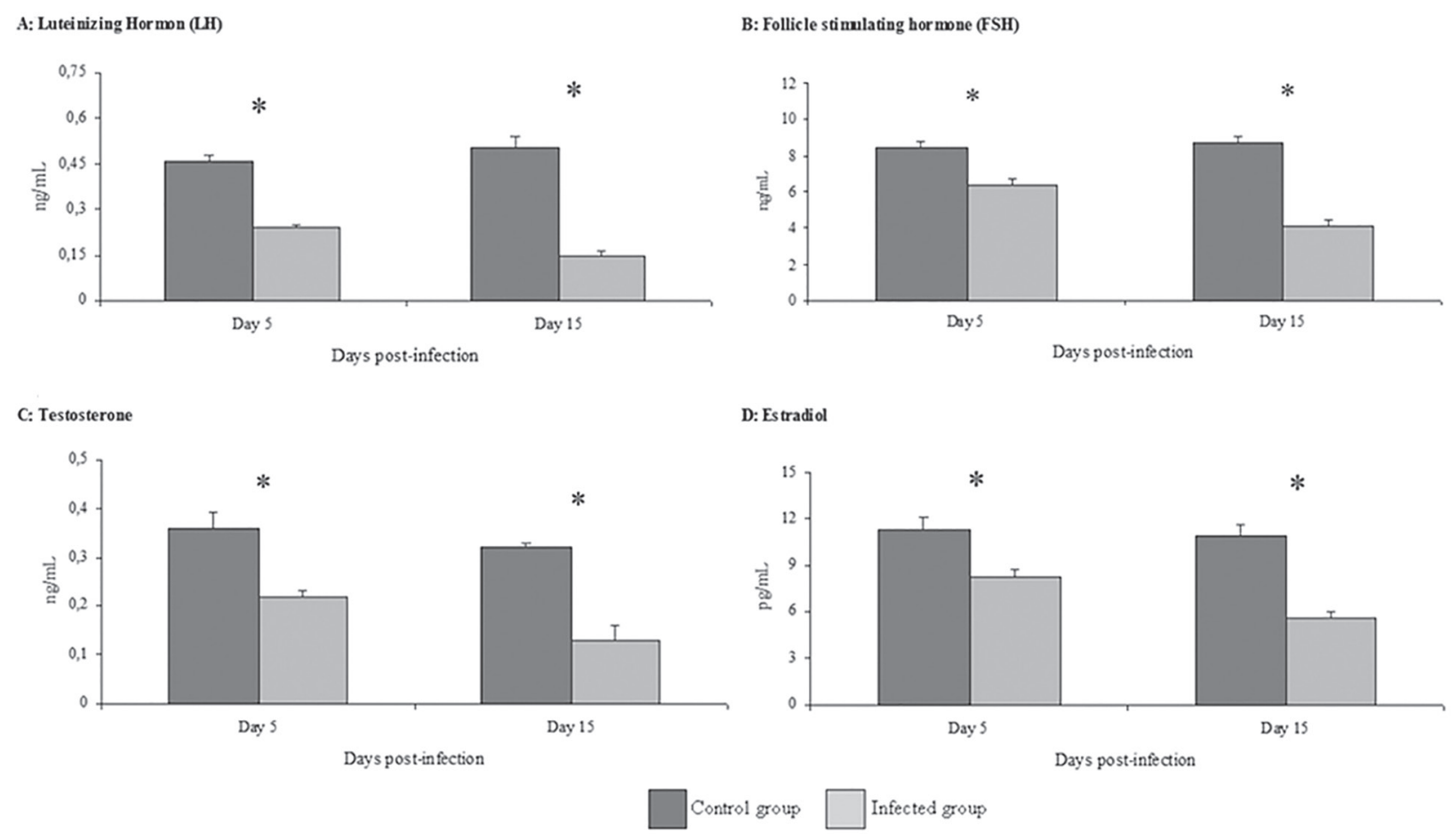

Figure 1 - Serum levels of luteinizing hormone (A), follicle stimulating hormone (B), testosterone (C) and estradiol (D) in rats experimentally infected with Trypanosoma evansi on days 5 and 15 PI compared to uninfected animals (Student: * P $<0.01$ ). 


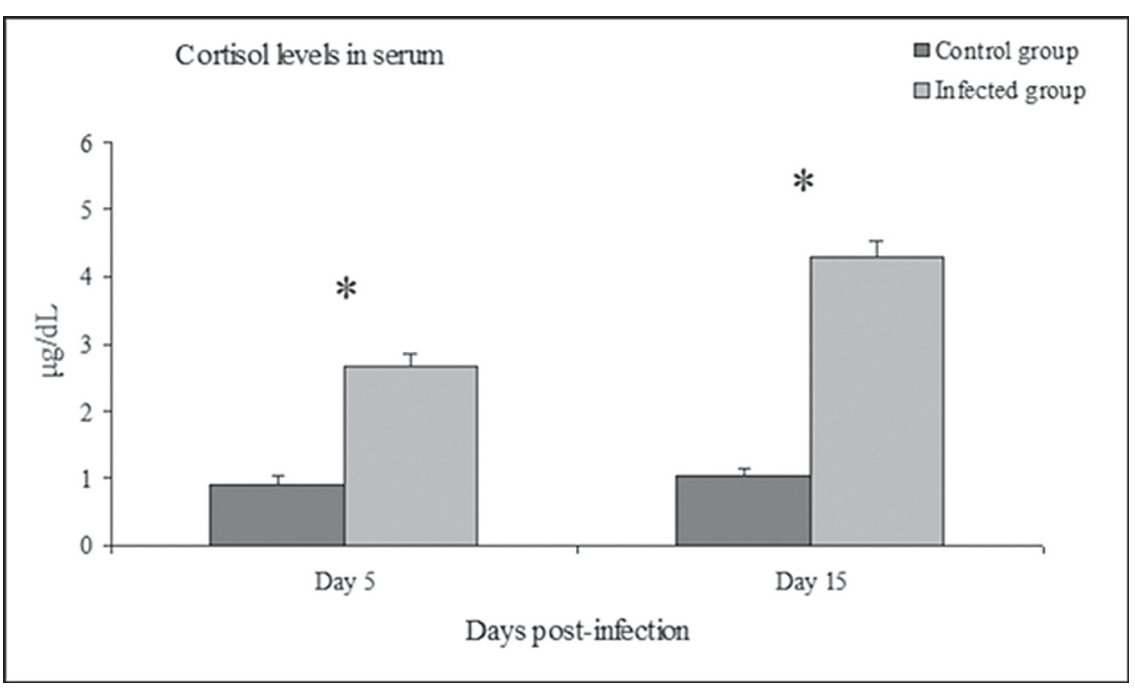

Figure 2 - Serum cortisol levels in rats experimentally infected with Trypanosoma evansi on days 5 and 15 PI compared to uninfected animals (Student: * $\mathrm{P}<0.01$ ).

TABLE II

Mean and standard deviation of biomarkers of cellular injury in testicles of rats experimentally infected with Trypanosoma evansi. Serum concentrations of nitrite/nitrate $\left(\mathrm{NO}_{\mathrm{x}}\right)$, thiobarbituric acid reactive substances (TBARS) and advanced oxidation protein products (AOPP) evaluated in the testicles of rats infected with $T$. evansi on days 5 and 15 post-infection.

\begin{tabular}{cccc}
\hline Variables & Days & Groups \\
\hline & & Uninfected & Infected \\
\hline NOx & 05 & $15.4^{\mathrm{a}}( \pm 3.4)$ & $33.1^{\mathrm{b}}( \pm 3.7)$ \\
$(\mu \mathrm{mol} / \mathrm{L})$ & 15 & $11.5^{\mathrm{a}}( \pm 3.7)$ & $23.9^{\mathrm{b}}( \pm 6.1)$ \\
\hline TBARS & 05 & $13.6^{\mathrm{a}}( \pm 2.7)$ & $23.1^{\mathrm{b}}( \pm 4.8)$ \\
$(\mu \mathrm{mol} \mathrm{MDA} / \mathrm{mg}$ of protein $)$ & 15 & $14.2^{\mathrm{a}}( \pm 3.1)$ & $25.7^{\mathrm{b}}( \pm 3.7)$ \\
\hline AOPP & 05 & $33.7^{\mathrm{a}}( \pm 7.9)$ & $48.2^{\mathrm{b}}( \pm 8.4)$ \\
$(\mu \mathrm{mol} / \mathrm{L})$ & 15 & $37.7^{\mathrm{a}}( \pm 9.1)$ & $51.1^{\mathrm{a}}( \pm 12.7)$ \\
\hline
\end{tabular}

Note: Means with equal letters, on the same line, do not differ statistically among themselves to $5 \%$ of significance $(\mathrm{P}>0.05)$.
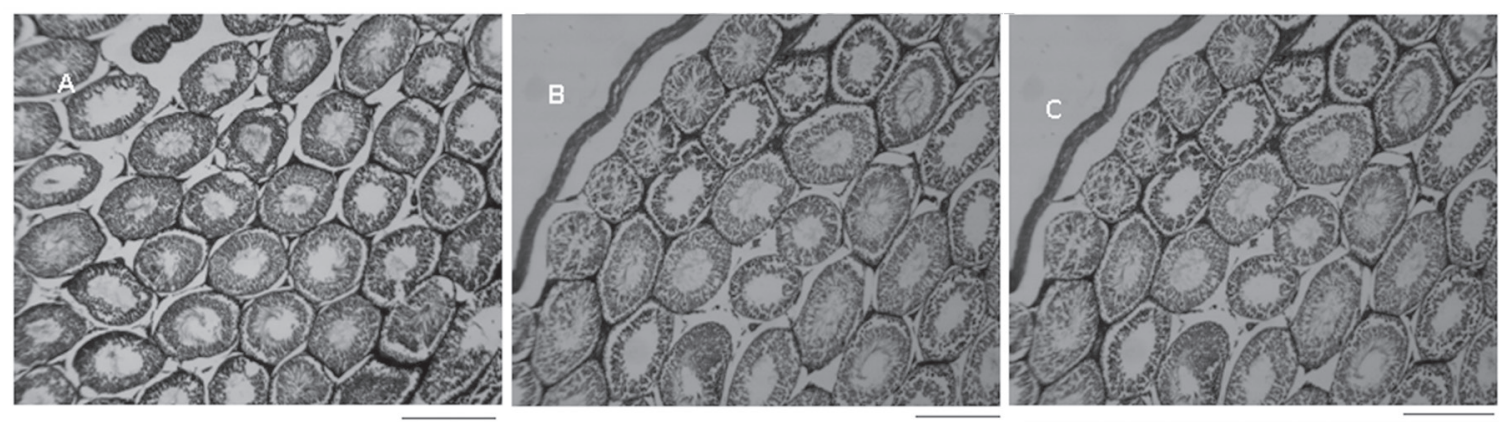

Figure 3 - Histology of testicls in rats experimentally infected with Trypanosoma evansi. Seminiferous tubules of healthy animals (A) compared to rats infected at days 5 (B) and 15 (C) post-infection. It can be seen in testis animals infected with T. evansi a marked reduction of the thickness and an increase in the degeneration of the seminiferous epithelium as well as a reduction in the number of sperm in the lumen of the seminiferous tubule. Bar: $20 \mu \mathrm{m}$. 


\section{HISTOPATHOLOGY}

Significant histopathological alterations were observed in the infected animals (subgroups B1 and B2). Marked reduction of the thickness, along with an increased degeneration of the seminiferous epithelium was visualized. Associated with these alterations, a significant reduction in the number of sperm in the lumen of the seminiferous tubule was found (Figure 3).

\section{DISCUSSION}

Recently, our research group reported a reduction in the levels of LH, FSH, estradiol, and progesterone in female rats experimentally infected by $T$. evansi (Faccio et al. 2013). Decreased level of reproductive hormones associated with increase of biomarkers of oxidative stress $(\mathrm{NO}$, lipid peroxidation and protein oxidation) and degenerative lesions in the testes were observed in this study. The results obtained in hormonal assays are similar to those of other authors (Hublart et al. 1990), who worked with experimental infection with Trypanosoma brucei and reported reduction of serum testosterone levels, however, without alterations in levels of LH and FSH. In addition, researchers observed a reduction in serum LH, which, according to the authors, was due to decreased stimulation of GnRH, with consequent reduction in testosterone levels in rams infected with Trypanosoma congolense (Mutayoba et al. 1994). In camels infected with T. evansi an increase in estradiol levels and decreased levels of testosterone was observed, associated with reduced sperm counting and increased index of abnormal sperm (Al-Qarawi et al. 2004).

The rats infected with $T$. evansi in this experiment showed degeneration of the seminiferous tubules and reduction in the number of sperm in the lumen (Figure 3), in addition to causing morphological alterations in sperm of infected animals. In a study with deer infected with T. evansi, the same degeneration of the seminiferous tubule plus a spermatic degeneration in the epididymis ducts (Shehu et al. 2006) was also found. Such changes may reduce the reproductive capacity of male, as well as cause infertility with chronicity of the disease (Sekoni 1994). Authors reported that $T$. vivax can cause a drop in the quality and volume of semen, decrease sperm concentration and increase the number of teratozoospermias (Sekoni 1994). There are reports that animals experimentally infected with $T$. vivax showed a decrease of spermatogenic cells, destruction of interstitial tissue, hypoplastic seminiferous tubules, and disappearance of Sertoli cells with involvement of epididymis parenchyma (with focal areas of necrosis and squamous metaplasia) (Adamu et al. 2007).

A study using sheep infected with $T$. vivax exhibited marked testicular degeneration (Bezerra et al. 2006), where these changes may be related to the reduction of LH and FSH hormones that are stimulating steroidogenesis and spermatogenesis, respectively (Apted 1970, Jittapalapong et al. 2009). However, other alterations such as hyperthermia, anemia and anorexia would cause these kinds of changes (Setchell 1998). These clinical signs are often present in infection by T. evansi, which did not enable us to state that the testicular lesions observed in this study were caused directly by the infection of this flagellate, since the testicle is extremely sensitive to increases in temperature (Friedman et al. 1991). However, the presence of T. vivax in the testicles and semen of sheep was already reported (Bezerra et al. 2006), and may cause a local inflammatory response and tissue damage. In this study, the alterations observed in the testicles may be associated with reduced levels of circulating LH and FSH, since the direct gonadal lesion is able to determine an increase in the gonadotropins FSH and LH due to the failure in the self-regulation of the hypothalamic-pituitary-gonadal axis.

The infection by $T$. evansi in rats generates oxidative stress (Omer et al. 2007). In this study the levels of $\mathrm{NO}_{\mathrm{x}}$, TBARS and AOPP (only day 5 $\mathrm{PI})$ were increased in testicle of infected animals, 
similar result was observed previously in the serum of rats with trypanosomosis (Da Silva et al. 2012). These parameters suggest the occurrence of lipid peroxidation, protein oxidation and an increase in nitrite/nitrate levels (which can be interpreted as an increase in peroxynitrite, which at high levels is toxic to cell) in the testicles of these animals. The increase of these biomarkers was suggestive of cell injury and later confirmed by the histology of the organ. Cortisol is well known as a marker of stress; it was found increased in the serum of infected animals, might inhibit the release of GnRH (McGivern and Redei 1994) and, therefore, justifies the reduced levels of LH and FSH found in the serum of the animals infected with T. evansi.

The decrease in the levels of testosterone and estradiol in infected animals could be attributed to the degeneration of the seminiferous tubules. In the testicles, the Leydig cells are located (Stanbenfeldt and Edqvist 1996), where 95\% of blood circulating testosterone is produced (the rest is produced by the adrenal) (Dadoune and Demoulin 1993). Another explanation for the reduction of serum testosterone levels is due to a decrease in LH levels, since the production of testosterone is controlled by the secretion of this hormone, which also has a direct effect on Leydig cells, leading to hypertrophy of these cells (Stanbenfeldt and Edqvist 1996). The secretion of LH and testosterone levels are controlled by a negative feedback, i.e., an increase in the secretion of LH causes an increase in testosterone levels (Stanbenfeldt and Edqvist 1996).

The low dosage of FSH in T. evansi infected rats may have caused the low serum estradiol levels observed, since the follicle-stimulating hormone is responsible for converting the testosterone produced by Leydig cells in estrogen (Stanbenfeldt and Edqvist 1996). Estrogens are synthesized in the male reproductive system in Sertoli cells, Leydig cells, and germ cells in the brain (Hess et al. 2001). The role of this estrogen is to inhibit the synthesis of testosterone (Dadoune and Demoulin 1993). However, in the present study both were at lower levels when compared to infected animals.

The full cycle of sperm production takes 12 days to be completed in rats (Stanbenfeldt and Edqvist 1996); however, it can be affected in trypanosomosis (Al-Qarawi et al. 2004, Shehu et al. 2006, Bezerra et al. 2008). Previous studies of our research group showed that during the parasitemia peak the body temperature of the animals were high (Da Silva et al. 2012). Therefore the hyperthermia may have contributed to the testicular pathologies observed.

Based on the results, we were able to verify that the experimental infection with $T$. evansi in rats causes a reduction in serum levels of reproductive hormones (LH, FSH, testosterone and estradiol) and increases the serum levels of $\mathrm{NO}_{\mathrm{x}}$, TBARS, AOPP, and cortisol associated with marked testicular tissue damage and morphological disorders in sperm. It is believed that events have occurred in sequence as discussed before, because a situation of oxidative stress observed in rats infected with T. evansi may have inhibited the levels of LH and FSH. This fact could lead to histological lesions in the testicle and consequently interfere with the production of testosterone and estradiol. These damages are probably the main reason for the alterations observed, supporting our conclusion that these flagellate are able to contribute to the infertility in male rats either directly or indirectly.

\section{RESUMO}

O objetivo deste estudo foi avaliar a relação entre lesões testiculares e os níveis hormonais em ratos infectados experimentalmente por Trypanosoma evansi. Para isso, a mensuração de hormônios reprodutivos, histopatologia e biomarcadores de lesão celular foi realizada em 24 animais, que foram divididos em dois grupos com 12 animais cada. Grupo A foi usado como controle negativo, não infectado, enquanto o grupo B foi composto por animais infectados com T. evansi. Ambos os grupos foram divididos em dois subgrupos $(n=6)$, então soro e fragmentos testiculares foram colhidos no dia 5 (A1 e B1) e 15 (A2 e B2) pós- 
infecção (PI). A análise morfológica mostrou aumento de alterações de cabeça e cauda de espermatozóides em ratos infectados quando comparados aos do grupo controle. Uma redução significativa $(\mathrm{P}<0,01)$ nos níveis de LH, FSH, estradiol e testosterone associado com um aumento do cortisol foi observada no soro dos ratos do grupo B quando comparado com grupo A. Além disso, o $\mathrm{NO}_{\mathrm{x}}$, peroxidação lipídica e oxidação proteica foram elevados nos testículos, indicando a ocorrência de lesão celular. Pela histopatologia foi possível observar uma degeneração testicular, entre outras alterações nos animais infectados. Portanto, com base nestes resultados é possível concluir que a infecção experimental por T. evansi causou mudanças nos níveis dos principais hormônios em ratos machos associados com lesão celular.

Palavras-chave: protozoários, ratos Wistar, lesão testicular, reprodução, estresse oxidativo.

\section{REFERENCES}

Adamu S, Fatihu MY, Useh NM, Mamman M, Sekoni VO AND ESIEVO KAN. 2007. Sequential testicular and epididymal damage in Zebu bulls experimentally infected with Trypanosoma vivax. Vet Parasitol 143: 29-34.

AL-QARAWI AA, OMAR HM, ABDEL-RAHMAn HA, EL-MougY SA AND EL-BELELY MS. 2004. Trypanosomiasis-induced infertility in dromedary (Camelus dromedarius) bulls: changes in plasma steroids concentration and semen characteristics. Anim Reprod Sci 84: 73-82.

APTED PIC. 1970. Clinical manifestations and diagnosis os sleeping sickness, In: MULLIGAN EW and POTTS WH (Eds), The African Trypanosomiasis. Allen \& Unwin, Ld, p. 661-683.

BARTH AD AND OKO RJ. 1989. Abnormal morphology of bovine spermatozoa. $1^{\text {st }}$ ed., Iowa: Ames, 285 p.

BATISTA JS, BEZERRA FSB, LiRA RA, CARVAlHo JRG, Neto AMR, Petri AA AND TeIXeIrA MMG. 2008. Aspectos clínicos, epidemiológicos e patológicos da infecção natural em bovinos por Trypanosoma vivax na Paraíba. Pesq Vet Bras 28: 63-69.

Batista JS, Riet-Correa F, TEIXEIRA MM, Madruga CR, SimõES SD AND MAIA TF. 2007. Trypanosomiasis by Trypanosoma vivax in cattle in the Brazilian semiarid: Description of an outbreak and lesions in the nervous system. Vet Parasitol 143: 174-181.

BEZERra FSB, BATISTA JS, SOUSA FDN, LiRA RA, CARVALHO JRG AND GODOI RMI. 2006. Aspectos clínicos e reprodutivos da infecção natural por Trypanosoma vivax em bovinos leiteiros no Alto Sertão da Paraíba. In: Congresso Nordestino de Produção Animal, Petrolina, PB, p. 1135-1137.
Bezerra FSB, Garcia HA, Alves HM, Oliveira IRS, SILVA AE, TEIXEIRA MMG AND BATISTA JS. 2008. Trypanosoma vivax nos tecidos testicular e epididimário de ovinos experimentalmente infectados. Pesq Vet Bras 28: 575-582.

BLOM E. 1973. The ultrastructure of some caracteristic sperm defects and a proposal for a new classification of the bull spermogram. Nord Veterinaermed 25: 383-391.

Capeillére-Blandin C, Gausson V, Descamps-Latscha B AND WitKo-SARSAT V. 2004. Biochemical and spectrophotometric significance of advanced oxidized protein products. Biochim Biophys Acta 1689: 91-102.

CELEGHINI ECC. 2005. Efeitos da criopreservação do sêmen bovino sobre as membranas plasmática, acrossomal e mitocondrial e estrutura da cromatina dos espermatozóides utilizando sondas fluorescentes. Tese de Doutorado em Medicina Veterinária - Faculdade de Medicina Veterinária e Zootecnia, Universidade de São Paulo, São Paulo, 186 p.

ChatKIn JM, DJUPESLAND P, QIAN W, HAight J AND ZAMEL N. 2000. Óxido nítrico exalado no diagnóstico e acompanhamento das doenças respiratórias. J Pneumol 26: 36-43.

COlpo CB, Monteiro SG, StAinKI DR, COLPO ETB AND HENRIQUES GB. 2005. Infecção natural por Trypanosoma evansi em cão no Rio Grande do Sul. Ciênc Rural 35: 717-719.

Da Silva AS, Paim FC, Moresco RN, Monteiro SG AND LOPES STA. 2012. Nitric oxide level, protein oxidation and antioxidant enzymes in rats infected by Trypanosoma evansi. Exp Parasitol 132: 166-170.

DAdOUNE J AND DEMOULIN A. 1993. Structure and function of testis. In: THIBAULT C (Ed), Reproduction in mammals and man. Paris, Ellipses, p. 227-225.

DERIJK R AND BERKENBOSCH L. 1991. The immune-hypothalamo-pituitary-adrenal axis and autoimmunity. Int $\mathrm{J}$ Neurosci 59: 91-100.

DESCAMPS-LATSCHA B, WitKo-SARSAT V, NGUYEN-KHOA T, NGuYen AT, GAusson V, Mothu N, London GM AND JUNGERS P. 2005. Advanced oxidation protein products as risk factors for atherosclerotic cardiovascular events in nondiabetic predialysis patients. Am J Kidney Dis 45: 39-47.

Escobedo G, Roberts CW, CARrero JC AND MoralesMONTOR J. 2005. Parasite regulation by host hormones: an old mechanism of host exploitation? Trends Parasitol 21: 588-593.

ESTERBAUER H. 1993. Cytotoxicity and genotoxicity of lipidoxidation products. Am J Clin Nutr 57: 779S-785S.

FACCIO L ET AL. 2013. Serum levels of LH, FSH, estradiol and progesterone in female rats experimentally infected by Trypanosoma evansi. Exp Parasitol 135: 110-115.

Friedman R, Scott M, Heath SE, Hughes JP, DaEls PF AND TRAN TQ. 1991. The effects of increased testicular temperature on spermatogenesis in the stallion. J Reprod Fertil 44: 127-134.

Grossman CJ, Roselle GA And Mendenhall CL. 1991. Sex steroid regulation of autoimmunity. J Steroid Biochem Mol Biol 40: 649-659.

Halliwell B AND CHIRICO S. 1993. Lipid peroxidation: its mechanism, measurement, and significance. Am J Clin Nutr 57: 715S-725S. 
Hess RA, Zhou Q, Nie R, Oliveira C, Cho H, NAKAi M AND CARNES K. 2001. Estrogens and epididymal function. Reprod Fertil Develop 13: 273-283.

Hublart M, Tetaert D, Croix D, Boutignon F, Degand P AND BoERSMA A. 1990. Gonadotropic dysfunction produced by Trypanosoma brucei brucei in the rat. Acta Trop 47: 177-184.

JentZsCh AM, BACHMANN H, FÜRST P AND BIESALSKI HK 1996. Improved analysis of malondialdehyde in human body fluids. Free Radic Biol Med 20: 251-256.

JitTAPALAPONG S ET AL. 2009. Prevalence of Trypanosoma evansi infection causing abortion in dairy cows in Central Thailand. Kasetsart J 43: 53-57.

JOHNSON W. 1997. The significance to bull fertility of morphologically abnormal sperm. Vet Clin North Am 13: 255-270.

Lopes JL, CARVAlHo M, MoReira ME and CABral J. 1997. Oxido nitrico no tratamento da hipertensão pulmonar percistente do recem nascido. Rev Soc Boliviana de Pediatría 36: 33-38.

Mbaya AW, Nwosu CO And Kumshe HA. 2011. Genital lesions in male red fronted gazelles (Gazella rufifrons) experimentally infected with Trypanosoma brucei and the effect of melarsamine hydrochloride (Cymelarsan $\left.{ }^{\circledR}\right)$

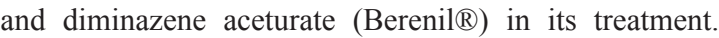
Theriogenol 76: 721-728.

Maudlin I, Holmes PH AND Miles MA. 2004. The trypanosomiases. Wallingford, CABI, $611 \mathrm{p}$.

MCGIVERN RF AND REDEI E. 1994. Adrenalectomy reverses stress-induced supression of luteinizinghormone secretion in long-term ovariectomized rats. Phisiol Behav 55: 1147-1150.

Mutayoba MB, Eckersal PD, JeFFCOATE IA, CESTNIK V AND HoLMES PH. 1994. Effectes of Trypanosoma congolense infection in rams on the pulsatile secretion of $\mathrm{LH}$ and testosrone and responses to injection of GnRH. J Reprod Fertil 102: 425-431.

OMer OH, Mousa HM AND AL-Wabel N. 2007. Study on the antioxidant status of rats experimentally infected with Trypanosoma evansi. Vet Parasitol 145: 142-145.

RANJITHKUMAR M, Kamili NM, SAXENA A, DAN A, DEY S AND RAUT SS. 2011. Disturbance of oxidant/antioxidant equilibrium in horses naturally infected with Trypanosoma evansi. Vet Parasitol 180: 349-353.

SALEH MA, AL-SALAHY MB AND SANOUSI SA. 2009. Oxidative stress in blood of camels (Camelus dromedaries) naturally infected with Trypanosoma evansi. Vet Parasitol 162: 192-199.

SAntiago CM, Fernandes CH, Nogueira MS, Veiga EV AND CÁRNIO EC. 2000. Utilização do óxido nítrico como terapêutica: implicações para a enfermagem. Rev Latinoamericana Enf 8: 76-82.
SEKONI VO. 1994. Reproductive disorders caused by animal trypanosomiases: A Review. Theriogenol 42: 557-570.

SEKONI VO, NJOKU CO, KUMI-DiAKA J AND SAROR DL. 1990. Pathological changes in male genital cattle infected with Trypanosoma vivax and Trypanosoma congolense. Braz Vet J 146: 175-180.

SEKONI VO, REKaWot PI AND BAWA EK. 2004. Effects of Trypanosoma vivax and Trypanosoma congolense infections on the reaction time and semen characteristics of Zebu (Bunaji) x Friesian crossbred bulls. Theriogenol 61: 174-194.

SETCHELl BP. 1998. The parkes lecture heat and the testis. J Reprod Fertil 114: 174-194.

SHEHU SA, IBRAHIM NDG, ESIEVO KAN AND MOHAMMED G. 2006. Pathology of experimental Trypanosoma evansi infection in Savannah Brown Buck. Pakistan J Biological Sci 9: 522-525.

Silva RAMS, PELlEgRIN AO, Lima ESS, RAMIREZ L AND DÁvILA AMR. 2004. Abortos por Trypanosoma vivax no Pantanal Mato-Grossense e Bolívia. EMBRAPA. Corumbá MS, Brasil, 30 p.

Silva RAMS, SEIDL A, RAMIREZ L AND DÁVILA AMR. 2002. Trypanosoma evansi e Trypanosoma vivax - Biologia diagnóstico e controle, EMBRAPA. Corumbá MS, Brasil, $137 \mathrm{p}$.

STANBENFELDT GH AND EDQVIST L. 1996. Processos reprodutivos do macho. In: SWENSON MJ AND REECE WO (Eds), Dukes - fisiologia dos animais domésticos. Rio de Janeiro. Guanabara Koogan 35: 603-614.

STUEHR DJ. 1999. Mammalian nitric oxide synthases. Biochim Biophys Acta 1411: 217-230.

Tatsch E, Bochi GV, Pereira RS, Kober H, Agertt VA, De CAMpos MM, Gomes P, DuARTE MM AND MORESCO RN. 2011. A simple and inexpensive automated technique for measurement of serum nitrite/nitrate. Clin Biochem 44: 348-350.

TIETZ NW. 1995. Clinical guide to laboratory tests, $3^{\text {rd }}$ ed., Philadelphia, Saunders, p. 578-580.

WitKo-SARSAT V, FRIEDLANDER M, KHOA TN, CAPEILLÉREBlandin C, NGUYen AT, CANTEloup S, DAYER JM, JUNGERS P, DRÜEKE T AND DESCAMPS-LATSCHA B. 1998. Advanced oxidation protein products as a novel mediators of inflammation and monocyte activation in a chronic renal failure. J Immunol 161: 2524-2532. 